\title{
Motivational factors and awareness on financial aid to women entrepreneurs with special reference to kannur and kasaragod districts of Kerala
}

\author{
Soji M Sebastian ${ }^{1 *}$, N. Karunakaran ${ }^{2}$ \\ ${ }^{\mathbf{1}}$ Assistant Professor, ${ }^{2}$ Principal and Research Guide in Economics of Kannur University, ${ }^{\mathbf{1}}$ Dept. of Commerce, ${ }^{\mathbf{2}}$ Dept. of Economics, ${ }^{\mathbf{1}} \mathrm{EK}$ \\ Nayanar Memorial Government College, Elerithattu, Kerala, India. ${ }^{2}$ People Institute of Management Studies, Kasaragod, Kerala, India \\ *Corresponding Author: N. Karunakaran \\ Email: narankarun@gmail.com
}

\begin{abstract}
Women constitute nearly 50 percent of world population. In traditional societies, they are confined to perform household activities and are generally called home makers. In modern society, they are taking part in all areas of life and seen in academic, teaching, politics, administration, software development, banking sector, hospitals and so on. Today, the entrepreneurial world is also open to women folk. It is estimated that women entrepreneurs comprises about 10 percent of the total entrepreneurs in India today. Government across the world and various development organizations are actively involved in the promotion of women entrepreneurs through various schemes, incentives and promotional measures. To understand the motivational factors influencing women to become entrepreneurs and various support systems to look at entrepreneurship is essential and is revealed that most of the women entrepreneurs lack proper awareness of such schemes.
\end{abstract}

Keywords: Motivational factors, Awareness, Financial aid, Women entrepreneurs, Kerala.

\section{Introduction}

Women entrepreneurship is an enterprise owned and controlled by a women having a minimum financial interest of 51 percent of capital and giving at least 51 percent of employment generated in the enterprise to women. In Kerala women industrial units are owned and organized by women and engaged in small scale and cottage industries with not less than 80 percent of total workers as women. Women entrepreneurs' enterprises is thus a small scale industrial unit or industrially related services or business enterprise managed by one or more women entrepreneurs in proprietary concerns in which she or they will individually or jointly have share capital of not less than 51 percent as partners or shareholders or directors of private limited company, members of co-operative society. As an economic organization woman entrepreneurs' contribution towards the economic development of a country is very high. A number of measures were undertaken by the government for the promotion of women entrepreneurship in India (Fezeena Khadir, et. al., 2019). To understand the motivational factors influencing women to become entrepreneurs and various support systems to look at entrepreneurship is essential and is attempted in this paper. More specifically, the main objectives include: (i) to study the motivational factors and various schemes of assistance influence women to be an entrepreneur, and (ii) to study the awareness of financial aid available to women entrepreneurs and sources of finance that the women use to start an enterprise.

\section{Materials and Methods}

Sharmina Afrin, et. al. (2008), and Ranbir Singh and Nisha Raghuvanshi (2012) studied the economic status of women and government policies for the development of entrepreneurship among women. Nirmala Karuna D'Ceruz (2003) and Vinisha Bose (2013) analyzed the social and organizational factors help people to perceive the opportunities for promoting and developing women entrepreneurs. Fezeena Khadir, et. al. (2019), Manjula R. Iyer (2019) observed that women have greater capacity and capability to contribute to the economic development of the country. Both primary and secondary data were used for the study. The theoretical aspects of motivational factors and various schemes available to women entrepreneurs were collected from various published and unpublished documents. Primary data were collected from 30 women entrepreneurs of Kannur and Kasargod district in Kerala using structured questionnaire.

\section{Results \\ Women entrepreneurship in Kerala}

Kerala has made significant progress in the field of social development and this is reflected in the highest literacy among women. A couple of decades ago the number of working women was very less, but recently, as the cost of living has increased, it is keenly felt the need to work outside. Rapid industrialization, socio-political movements and growth of science and technology also brought significant changes (Table 1). Among the districts, the lowest number of women entrepreneurs is in Kasaragod (Manjula R Iyer, 2019). Most of the units started by women utilized locally available raw materials. Recently, they entered in industries like garments, chemical and engineering units and computer services. Government introduced various schemes to bring women into the main stream of industries and many training programmes were organized, covering various aspects of modern management techniques and project implementation. 
Table 1: Participation of Women in Management/Ownership of SSI Sector in India

\begin{tabular}{|c|c|c|c|}
\hline $\begin{array}{l}\text { Sl. } \\
\text { No. }\end{array}$ & Major States/UTs & $\begin{array}{l}\text { Number of Enterprises } \\
\text { Managed by Women }\end{array}$ & $\begin{array}{l}\text { Number of Women } \\
\text { Enterprises }\end{array}$ \\
\hline 1 & Kerala & 137561 & 139225 \\
\hline 2. & Himachal Pradesh & 3515 & 3722 \\
\hline 3. & Punjab & 30190 & 29068 \\
\hline 4. & Chandigarh & 2059 & 2243 \\
\hline 5. & Uttaranchal & 8706 & 8804 \\
\hline 6. & Haryana & 10087 & 9620 \\
\hline 7. & Delhi & 13368 & 14383 \\
\hline 8. & Rajasthan & 29785 & 36371 \\
\hline 9. & Uttar Pradesh & 54491 & 72667 \\
\hline 10. & Bihar & 38170 & 49443 \\
\hline 11. & Sikkim & 30 & 98 \\
\hline 12. & Arunachal Pradesh & 131 & 150 \\
\hline 13. & Nagaland & 207 & 179 \\
\hline 14. & Manipur & 9168 & 10745 \\
\hline 15. & Mizoram & 3076 & 3700 \\
\hline 16. & Tripura & 631 & 863 \\
\hline 17. & Meghalaya & 3658 & 3580 \\
\hline 18. & Assam & 11189 & 11757 \\
\hline 19. & West Bengal & 71847 & 69625 \\
\hline 20. & Jharkhand & 7271 & 7865 \\
\hline 21. & Orissa & 33274 & 38233 \\
\hline 22. & Chhattisgarh & 11766 & 10034 \\
\hline 23. & Madhya Pradesh & 62351 & 68823 \\
\hline 24. & Gujarat & 55361 & 53703 \\
\hline 25. & Maharashtra & 80662 & 100670 \\
\hline 26. & Andhra Pradesh & 77347 & 77166 \\
\hline 27. & Karnataka & 101264 & 103169 \\
\hline 28. & Goa & 677 & 810 \\
\hline 29. & Tamil Nadu & 130289 & 129808 \\
\hline \multicolumn{2}{|c|}{ All India } & 995141 & 1063721 \\
\hline
\end{tabular}

\section{Factor motivating woman to be an entrepreneur}

Women set up an enterprise due to economic and noneconomic reasons which include (i) Motivational factors and (ii) Facilitating factors. Motivational factors consists of economic necessity, independence, Self-actualisation, and government policies like SBI Stree Shakti Package; IDBI Mahila Udyam nidhi Scheme; SIDBI's assistance for Women Entrepreneurs; Bank of India's Priyadarshine Yojana; Prime Minister RojgarYojana (PMRY); Self-Employment Programme for Urban Poor (SEPUP); Swarnajayanti Gram Swarozgar Yojana (SGSY); Integrated Rural Development Programme (IRDP); Micro-Finance through Rashtriya Mahila Kosh (RMK) and other scheme launched for the development of women entrepreneurs. Educational qualification, role model behavior of others like (Vandana Luthura (VLCC), Kiran Mazumdar Shaw (Biocon Ltd), Priya Paul (Park Hotel), Rithu Kumar (Fashion Designer), Suchi Mukherjee (Limeroad) Shahnaz Hussain (Beauty Clinic), Neena Malhotra, (Exports), Sminu Jindal (Steel Sector), Michelle Salins (Interior designer), Neety Singh (Jewellery designer)), employment generation, self-identity and social status, success stories and family occupation are also the motivational factors. The main facilitating factors are adequate financial facilities, self-satisfaction, innovative thinking, and co-operation of family, experienced and skilled people at work and support of family members.

\section{Schemes for women entrepreneurs}

The integrated scheme of assistance to women enterprises provided for identification, selection, training and consultancy and escort services apart from term loan facilities on concessional terms continue to receive interesting response. As a result, assistance to women entrepreneurs is increasing day-by-day and some of the schemes introduced to provide financial assistance to women entrepreneurs are:

\section{Government and Bank funding schemes to women entrepreneurs}

The Small Industry Development Bank of India (SIDBI) has special schemes for financial and managerial assistance for women entrepreneurs. The scheme is opened through State Financial Corporations' Banks, State Co-operative Banks and Regional Rural Banks. SIDBI refinance these institutions to the extent of assistance they provide. Bank of India Priyadarshini Yojana scheme provide long term working capital assistance to professional and self-employed, small business, general provision stores, cillage or Cottage and small scale industry, road transport operations and allied agricultural activity. IDBI has set up a special fund, Mahila 
Udayam Nidhi (MUN) with a Corpus of Rs. 5 core to provided seed capital assistance to women entrepreneurs. State Bank of India introduced Sree Sakthi Package aimed at reinforcing its efforts in the area of developing entrepreneurship among women. Mudra Yojana is offered by banks, NBFCs, and microfinance institutions. The government launched the Bhartiya Mahila Bank loan to offer financial assistance to women entrepreneurs involved in manufacturing businesses. Women entrepreneurs who are engaged in agricultural activities or similar small businesses are offered business loan under Udyogini scheme. Trade Related Entrepreneurship Assistance and Development (TREAD) scheme for women, Kalyani Scheme of Central Bank of India also provide assistance to both existing and new entrepreneurs and self-employed women for micro and small enterprises like farming, handicrafts, food-processing, garment making, beauty, canteen, mobile restaurants, circulating libraries, day crèches and tailoring. Dena Shakti Scheme offered by Dena Bank is also designed to empower women financially for businesses in the field of agriculture, manufacturing, education, housing, micro-credit, retail stores and small enterprises.

\section{Non-government funding scheme for women entrepreneurs} SAHA FUND is a first women-focused venture capital fund approved by the Securities and Exchange Board of India. Women Entrepreneurs India lends a helping hand to women in establishing their businesses with ideas that coincide with their abilities, interests and skills, and to upscale their existing business. SONDER CONNECT aims to create a pipeline of high-potential women entrepreneurs and assist them in scaling by connecting them to investors and providing access to a powerful global network. They support women in their entrepreneurial journey to become self-governing and guide them to thrive in their endeavours through comprehensive, expert-led mentoring programmes. HERMONEY TALKS is India's first financial services market place for women aim in connecting women to financial institutions and facilitate credit for women. CASH SUVIDHA is a micro-lending platform for Women that offer lower interest rates and less supporting documentation to help women in India to sustain their businesses. The platform has its own 'Suvidha Score' system to determine applicants' creditworthiness for instant loan approval and disbursement. CROWDFUNDING is an innovative way of accessing funds. Crowd funding platforms are spaces for fund raisers and the crowd to interact, where small amounts can be sourced from a large number of individuals to finance one's venture.

\section{Women entrepreneurs in Kannur and Kasargod District of Kerala}

Data on women entrepreneurs was collected from Kannur and Kasargod districts of Kerala. Educational qualification of them are SSLC (3.33 percent), Higher Secondary (30 percent), Degree (50 percent) and above graduation (16.33 percent). Out of these 73.6 percent are married, 20 percent unmarried and 6.6 percent widows. The main results identified are:
1. Women entrepreneurs are educated and enthusiastic to start a new venture.

2. They are mainly concentrated in medium scale enterprises.

3. Skill knowledge and desire are the main motive factors that most women to be an entrepreneur. Financial independence and setting up of a separate identity is also an important factor; passion for business is comparatively very low.

4. More than 57 percent of women entrepreneurs are not aware of the schemes introduced; among 43 percent aware about these only 8 percent have availed such schemes.

5. Around 43 percent depended on bank loan for their initial capital, whereas some used their own fund (23.33 percent and 26.66 percent collected from their friends. Only 3 percent used fund from Government aids and none of them depended on NGO's.

6. Almost 73 percent of women entrepreneurs get support from their family and only a few of them (26.66 percent) are not completely satisfied with their family support.

7. Classes and training programmes to women entrepreneurs to solve the problem of lack of awareness on financial aid to women entrepreneurs in local areas is suggested by majority of respondents.

8. Majority of women faced lot of challenges but almost all of them feel that the title of being an entrepreneur gives them a status in the society. Almost all gets support from their family.

\section{Conclusion}

Women constitute a decisive force and the future destiny of the world is unavoidably blended. The best way to realize the man-woman equality and harmony is bringing them into the main stream of economic activity by extending all possible assistance to help in recognizing and using all talents, capabilities and potential power and thus building up a progressive modern India. Therefore the present institutional system to support the sustainable development of women entrepreneurship is fully utilized and further programmes in this respect may be initiated. Only a less percent of female population has taken up entrepreneurship as a career and among them few have availed governmental incentives and NGO assistance. The study revealed that most of the women entrepreneurs are well educated and the increase in their quality required better financial incentives showing more awareness programmes, proper support and encouragement to solve their problems in an effective manner.

\section{Source of Funding}

None.

\section{Conflict of Interest}

None.

\section{References}

1. Khadir F, Pigares E, Asif NB, Rithu AR, Jilda S, Joseph SM. "Challenges Faced by Established Women Fashion 
Entrepreneurs in Kerala During Initial Business Stage”, $J$ Marketing Vistas. 2019;9(1):13-20.

2. Iyer MR, "Problems Faced by Women Entrepreneurs in Ernakulam District, Kerala “, Commerce Spectr. 2019;5(2):1922.

3. D'Cruz NK. "Constraints on Women Entrepreneurship Development in Kerala: An analysis of family, social, and psychological dimensions", Discussion Paper No. 53, Kerala Research Programme on Local Level Development, Centre for Development Studies, Thiruvananthapuram. 2003.

4. Singh R, Raghuvanshi N. "Women Entrepreneurship Issues, Challenges And Empowerment through Self Help Groups: An Overview Of Himachal Pradesh1", Int J Manag Res Rev. 2012;2(1):2249-56.

5. Afrin S, Islam N, Ahmed SU. "A multivariate Model of Micro Credit and Rural Women Entrepreneurship Development in Bangladesh”, Int J Business Manag.(2008);3(8):169-85.
6. Vinisha Bose. "Role of Entrepreneurship development agencies in promoting women Entrepreneurship: a study of Kerala", $J$ Business Manag Invention. 2013;2(7):60-7.

How to cite: Sebastian SM, Karunakaran N. Motivational factors and Awareness on Financial Aid to Women entrepreneurs with special reference to Kannur and Kasaragod districts of Kerala. J Manag Res Anal. 2020;7(3):107-10. 